\title{
Research on Universities Computer Basic Curriculum Construction for Cultivating Students' Innovative Thinking and Calculation Ability
}

\author{
Yangqing Zhu \\ Electronic and Information Engineering School \\ Foshan University \\ Foshan City, Guangdong Province, China \\ zhuyangqing_830516@163.com
}

\begin{abstract}
The development stages, current situation and shortages of computer basic education in Chinese Universities were analyzed in this paper. In March 2014, the university liberal arts computer basic teaching reform file was published by Liberal Arts University Computer Basis Teaching Guidance Committee of Ministry of Education of the People's Republic of China. According to the file, combined with the computer basic teaching reform of the Business School in Foshan University, proposed the computer basis teaching curriculum for training students' innovative thinking and computing ability, designed the curriculum and learning assessment scheme, carried out teaching resource construction and learning strategies to improve students' innovative thinking and calculation ability. The researches provided reference solution for the computer basis education reform of the liberal arts of university in China.
\end{abstract}

Keywords- innovative thinking; calculation ability; computer Basis education; curriculum construction; comprehensive cultivation

\section{INTRODUCTION}

At present, many college teachers thought that computer basic course is to teach students how to use the computer, so that formed a "narrow tools" theory, as in [1]. At the same time, due to the use of inappropriate teaching methods, result in not good teaching effects. How to position computer basis teaching and reform course contents to adapt the social development are the important challenge. This paper analyzed the development stages, current situation and shortages of computer basic education in Chinese universities, designed the curriculum and assessment scheme, carried out teaching resource construction and learning strategies to improve students' innovative thinking and calculation ability. The researches provided reference solution for the computer basic education reform of the liberal arts of university in China.

\section{DeVELOPMENT STAges OF COMPUTER BASIC EDUCATION IN CHINESE UNIVERSITY}

Chinese university computer basic education is divided into five stages of development.

\section{A. The Beginning Stage}

In last century 80's, initially computer courses only were set up in computer majors of Chinese universities. In order to adapt to the rapid development and wide application of international computer technology, some experts called on that some computer courses should be set up in non- computer specialties in Chinese universities. As distinguished from the computer professional education, put forward the university computer basic education. During this period, the teachers mainly taught Basic programming language.

\section{B. The Popular Stage}

In twentieth century 90's, computer basis course teaching contents were from BASIC language extended to the Pascal, Fortran, Cobol, dBase III, FoxBASE, FoxPro and C language course. From the beginning of 1996, except for programming languages, some universities began to teach students to use Window Operation System and Office software.

\section{The High Speed Development Stage}

In the late twentieth Century to present, Internet and information technology completely changed the way of human life and production, computer technology has penetrated into every social field. Faced the rapid development of computer technologies, students increasingly requested raising their level of computer knowledge, therefore, development of computer basic education in Chinese universities must adapt with the actual demand. At this stage, the teaching content of college computer basis courses mainly included computer basic theory knowledge and simple skill operation. Computer basic theory knowledge mainly included computer development history, the structure and working principle of the computer system, different number conversion and coding scheme, the digital multimedia technology and application, computer virus and prevention, network technology, database and application , and simple programming language etc.. The operation skill training contents included the learning of Windows Operation System, Word, Excel, PowerPoint, simple database operation, simple programming and debugging, the use of Internet, making Webpage and so on.

D. The Stage of Taking Computational Thinking as the Core of Computer Basic Teaching Reform

In March 2006, Professor Yizhen Zhou of the Carnegie Mellon University put forward the notion of Computational Thinking. In recent years, Computational Thinking Ability Training has become a hot issue in computer education research in domestic and foreign, as in [2]. 
At this stage, in the basis of strengthening the students' computer basic knowledge and application skills, the overall goal of the computer basis teaching reform were more focusing on training students' the ability of solving professional problems with computing thinking, and improving students' innovative practical ability, as in [3].

\section{E. The New Stage of Emphasizing Service in Employment, Entrepreneurship and Innovation}

In March 2014, the university liberal arts computer basic teaching reform document was published by Liberal Arts University Computer Basis Teaching Guidance Committee of Ministry of Education of the People's Republic of China. The document pointed out that the university liberal arts computer basic education was the computer education system of noncomputer professional, scientific planning knowledge structure and course system, exploring computer education laws and methods, probing into effective ways for training liberal arts students' diverse thinking, the university computer basic teaching reform should be carried out in order to the different professional types and application demand. The document also pointed out that university computer teaching's overall goal is to train students' ability of computer knowledge, technology and application for serving employment and professional to cultivate more innovation and entrepreneurial talents. The teaching contents were to cultivate students' information literacy and application ability as the main line, to carry out the research on the arts university computer teaching reform, included understanding great contribution of information application to the economic and social development, understanding the mutual penetration of information technology and the humanities and social sciences, understanding and mastering the ideas and practices of solving professional field problems with computational thinking and computational tools. From then, the university computer basis education has entered a new stage of emphasizing service in employment, entrepreneurship and innovation, as in [4].

\section{The Present Situation of COMPUter Teaching FOR NON-COMPUTER MAJOR IN CHINA}

Up to now, the computer basis courses teaching was the contents of third stage in the most universities in China, mainly included two parts, they were basic computer theory knowledge teaching and simple operation skills training. There were some related courses, for example, the university computer basis, Internet and multimedia, Visual Basic, Visual FoxPro, Access database, $\mathrm{C}$ programming, and so on. The related researches were starting from these courses teaching, to explore the improvement of teaching quality, did not carry out the research of combining computer basis education with students themselves specialty, employment, entrepreneurship and innovation, as in [5].

The development of computer technology and application, has exerted profound influence on the various social fields, including people's daily life, work and study, even the people thought and thinking. How to guide college students to use computer technology for the social service, to better serve their own employment, entrepreneurship and innovation, was the teaching content that university computer basis courses should be done. However, there aren't these contents in the present university computer basis curriculum, it is an important reform direction in urgent need, as in [6].

\section{THE CONSTRUCTION OF CURRICULUM SYSTEM}

Today's computer technology has been applied to all aspects of society, has brought great convenience for people's work, study and life, improved society progress and civilization, as in [7]. As the economic management specialty students, they will move toward various enterprises and institutions of the society after graduation, they should have advanced computer knowledge, and can put computer technology and economy, management work together, to create efficient management and operation mode, to create greater benefit for their work units. At the same time, except for working in the various enterprises and institutions, they should enhance their entrepreneurial consciousness, thinking and ability. The Internet, mobile Internet, cloud computing and Internet of things provide efficient, flexible, easily expand platforms for college students entrepreneurship. The university students learn the latest computer technology, innovation and entrepreneurship case will offer great help for promoting the students to master the latest computer technology knowledge and innovation, entrepreneurial thinking and ability, bring the positive significance for social progress and appearance changing, so as to enhance the degree of civilization of the whole society. According to this idea, we carried out construction of computer basis courses of the economic management professional in Chinese university, mainly included two courses, the first course is Computer Technology and Civilization, the second course is The Application of Excel in Business.

\section{A. Construction of Computer Technology and Civilization}

1) Basic contents: The course of Computer Technology and Civilization took cultivating students' creative thinking as its goal, laid firm innovation thought for learning of the follow-up professional courses, made students to keep thinking about how to apply the professional knowledge combined with Internet, mobile Internet, cloud computing and Internet of things platform to create new knowledge and entrepreneurial practice in the professional learning process. This course was taught in the form of special topic, there were 11 special topics. These special topics include computer basic knowledge, computer hardware system, programming language, operating system, computer network, data processing, multimedia, information security, artificial intelligence, electronic commerce, a new generation information technology (cloud computing, Internet of things, mobile Internet) etc.. Each topic introduced basic content and latest development of the related technology and its application in social every fields, choose innovation and entrepreneurship cases, offered a great help for students to master necessary computer knowledge and improve their innovation and entrepreneurial thinking.

2) Teaching Plan: The course teaching time was 32 class hours, 2 credits. The concrete teaching plan as shown in table 1. 
TABLE I. TEACHING Plan OF THE COURSE OF COMPUTER TECHNOLOGY AND CIVILIZATION

\begin{tabular}{|l|r|}
\hline \multicolumn{1}{|c|}{ Teaching Contents } & Class Hours \\
\hline Computer Basic Knowledge & 2 \\
\hline Computer Hardware System & 2 \\
\hline Computer Assembling Experiment & 2 \\
\hline Programming Language & 2 \\
\hline Operating System & 2 \\
\hline Computer Network & 2 \\
\hline Computer Network Assembly Experiment & 2 \\
\hline Data Processing & 2 \\
\hline Multimedia & 2 \\
\hline Information Security & 2 \\
\hline Artificial Intelligence & 2 \\
\hline Artificial Intelligent Video & 2 \\
\hline Electronic Commerce & 2 \\
\hline The New Generation Information & 2 \\
\hline The New Generation Information Video & 32 \\
\hline The Course Report & \\
\hline Total Time & 2 \\
\hline
\end{tabular}

\section{B. Construction of the Application of Excel in Business}

1) Basic contents: The course of Application of Excel in Business combined with the enterprise operation process, systemly taught data acquisition, a variety of Excel data analysis tools, charts and how to use data analysis results, trained students' the comprehensive calculating ability, enhanced students' computational thinking, make students to understand the data significance of every case, expanded students' learning and application space, laid a solid foundation for students' future learning specialty courses and work. This course mainly included the basic knowledge of Excel, Excel applies in the production, sale, human resources management, financial management and national economic management. Through teaching the Excel application cases in the enterprise actual operation process, not only let students learn how to use Excel tools, more to enable students to understand the enterprise actual operation process and related data processing, laid the foundation for students to carry out follow-up professional courses, and make students directly use the Excel knowledge to solve data analysis problems in the production, sales and management after work.

2) Teaching Plan: The course teaching time included 24 class hours and 24 lab class hours, 3 credits. The concrete teaching plan as shown in table 2 .
TABLE II. TEACHING Plan of THE COURSE OF APplicAtion OF EXCEL IN BUSINESS

\begin{tabular}{|l|r|r|}
\hline Teaching Contents & Class Hours & Lab Class Hours \\
\hline The Basic Knowledge of Excel & 2 & 2 \\
\hline Excel Applies in the Production & 6 & 6 \\
\hline Excel Applies in the Sale & 6 & 6 \\
\hline $\begin{array}{l}\text { Excel Applies in the Human Resources } \\
\text { Management }\end{array}$ & 6 & 6 \\
\hline $\begin{array}{l}\text { Excel Applies in the Financial } \\
\text { Management }\end{array}$ & 2 & 2 \\
\hline $\begin{array}{l}\text { Excel Applies in the national economic } \\
\text { management }\end{array}$ & 2 & 2 \\
\hline Total Time & 24 & 24 \\
\hline
\end{tabular}

\section{TEACHING STRATEgIES}

Through setting up curriculum evaluation scheme, network teaching resources and network learning strategies to promote students' autonomous learning and cooperative learning habits.

\section{A. The Formulation of Curriculum Evaluation Scheme}

Learning evaluation is the lever of guiding students to learn. A good curriculum evaluation scheme becomes an important guarantee measure for cultivating students' innovative thinking and calculation ability, as in [8].

1) The Course Evaluation Scheme of Computer Technology and Civilization.

a) The Usual Assessment: The usual assessment included classroom questioning, homework and course report. To answer questions in class, who first hand up who first answer. Students can prepare in advance, and carefully listen to the teacher's teaching in class, to keep up with the teacher's teaching thinking path, always pay attention to the teacher's offering question, to have the opportunity to answer the question. The homework refers to each student completes a certain number of open questions. What students complete this part of the assignment need to look up a large number of documents via the Internet, Chinese China Knowledge Resource Integrated Database and other platforms, and summarize the documents to form their own view, constitute the logic rational and new view contents. The students' independent thinking and independent learning habits can be cultivated in this way. The assignment contents included commenting to the IBM enterprise president's enterprises management and entrepreneurial spirit, stating Internet enterprise demand, the students learning and occupation demand, discussing construction of Internet application system and its operation mode, analyzing data processing, discussing the influence of the artificial intelligence technology on people's life, setting up a business plan with the new generation of information technology platform etc.. Completing such homework can promote students to learn entrepreneurs and scientists innovative spirit and humanistic spirit, which can cultivate students' logical thinking, creative thinking and innovation ability. Assigning the homework in the open questions, the number of homework should not be too much, 6-8 was better, on average every 2 weeks 1 . In this way, students have more sufficient time to look up and summary documents, not only conducive to the improvement of the 
quality of work, but also will not affect the learning of other courses. Course report mainly included reviewing on the course content and teaching, how to carry out innovation learning, entrepreneurship and innovation practice in the follow-up professional courses learning in the university.

b) The Final Examination: The final examination can be carried out by computer test system. Questions highly summarizes the contents of this course, included the contents of computer theory and technology, the famous scientists' and entrepreneurs' innovation spirit, dedication spirit and adventure spirit of promoting the development and invention of computer technology. Students need to read textbooks, relevant websites and magazines to get good grades.

2) The Course Evaluation Scheme of Application of Excel in Business.

a) The Usual Assessment: The usual assessment included classroom questioning and computer operation work. The course classroom questioning evaluation scheme was the same as Computer Technology and Civilization. The computer operation work refers to each student completed a certain number of operation questions. The computer operation work were consisted of question cases from the enterprise's production, sales, financial management, human resources management and the related aspects. Through completing each computer operation work, students not only can learn Excel data analysis knowledge, also can understand business process and the actual operation data processing, so improve their comprehensive analyzing problems, solving problems and calculating ability, thus cultivating students' computational thinking.

b) The Final Examination: The final examination can be carried out by computer test system. The tests questions included theory and computer operation questions. The theoretical topics highly summarize the contents of this course, include single-choice, multiple-choice and judging questions. Computer operation questions were choose from the enterprise actual operation cases. Students need to read textbooks, relevant websites and magazines, and usually to enhance practical ability training to get good grades.

\section{B. Construction of Network Teaching Resources}

In order to the current computer technology development characteristics and rules, the teaching resources construction refers to the construction of teaching materials, electronic lesson plans, network teaching resources, examination question database etc.. In the project, the two textbooks of Computer Technology \& Civilization and Application of Excel in Business have been set up, has formed the electronic teaching materials conductive to teachers' teaching and students' learning, selected some videos, developed examination question database, and recommended learning websites to the students. Through these resources construction, ensure that students have enough resources for their independent learning.

\section{Network Learning}

According to the teaching resources and recommended websites, guided the students' autonomous learning. Students looked up information from some famous website (such as IBM, Microsoft, Oracle, Internet Congress website etc.), to enrich their own knowledge, understand the latest development of computer technology. At the same time, carried out teaching and learning discussion by Weibo and Weixin platforms. Thus, the students' autonomous learning and cooperation ability were cultivated.

\section{CONCLUSIONS}

At present, the majority of our country colleges and universities, especially local colleges computer basic courses teaching basically stay in the stage of computer tool theory, only few of colleges involve the cultivation of Computational Thinking of fourth stage, not start teaching reform of the fifth stage.

This article was started from the perspective of economics and management majors students' future employment, entrepreneurship and innovation, combined with the personnel training system, set up the curriculum system of computer basis courses combining with specialty and employment, through the cultivation of the students' calculation ability to enhance students' calculation thinking. Curriculum system contents not only reflect the latest development of the computer technology, and the fusion of humane spirit, improve the comprehensive quality of college students, cultivate useful talents for the society. Research and practice of this paper, will be in the colleges and universities of our country, especially in local universities, plays a leading role of demonstration in the computer basis course teaching reform, it has great application value.

\section{REFERENCES}

[1] Keding Yuan. Discussion on Methodological Orientation of University Computer Courses. China University Teaching, 2012.10: pp.9-12

[2] Qianming He, Hanquan Lu, Boqin Feng. The Core Task of Computer Basic Teaching Is Cultivating Computational Thinking Ability. China University Teaching, 2010.10: pp.5-9

[3] Jing Bian. Exploration of University Computer Basic Teaching Reform under Calculation Thinking. Course Education Research, 2014.11: pp.241

[4] Liberal Arts Colleges Computer Basic Teaching Instruction Committee Document of Ministry of Education of the People's Republic of China. Notice on Carrying out Computer Teaching Reform Projects of Liberal Arts University. http://www.wkjsj.org/Article_Show.asp?ArticleID=275. 2014.3

[5] Jie Bao. The University Computer Education Reform Trends in the New Period. Computer Education, 2013.4: pp.17-20

[6] Hong Lan, Shuzhi Li, Jianghua Li. Research on Local Colleges and Universities Computer Talent Ability Training Strategy. Journal of Jiangxi University of Science and Technology, 2013.8: pp.87-91

[7] Yaqin Zhu. An analysis of the development trend of computer technology. The Application of Computer Technology, 2014.7: pp.206-207

[8] Hao Zhang, Xiujuan Wu, Jing Wang. Study on the Evaluation Theoretical Structure Building of Deep Learning. Theory of Educational Technology, 2014.7: pp.51-55 